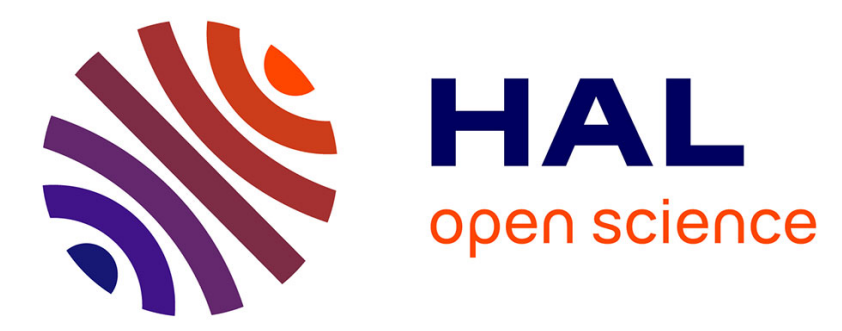

\title{
Phase equilibrium constraints on the viscosity of silicic magmas 1. Volcanic-plutonic comparison
}

Bruno Scaillet, François Holtz, Michel Pichavant

\section{To cite this version:}

Bruno Scaillet, François Holtz, Michel Pichavant. Phase equilibrium constraints on the viscosity of silicic magmas 1. Volcanic-plutonic comparison. Journal of Geophysical Research: Solid Earth, 1998, 103 (B11), pp.27,257-27,266. 10.1029/98JB02469 . insu-00717688

\section{HAL Id: insu-00717688 \\ https://hal-insu.archives-ouvertes.fr/insu-00717688}

Submitted on 13 Jul 2012

HAL is a multi-disciplinary open access archive for the deposit and dissemination of scientific research documents, whether they are published or not. The documents may come from teaching and research institutions in France or abroad, or from public or private research centers.
L'archive ouverte pluridisciplinaire HAL, est destinée au dépôt et à la diffusion de documents scientifiques de niveau recherche, publiés ou non, émanant des établissements d'enseignement et de recherche français ou étrangers, des laboratoires publics ou privés. 


\title{
Phase equilibrium constraints on the viscosity of silicic magmas 1. Volcanic-plutonic comparison
}

\author{
Bruno Scaillet, François Holtz,' and Michel Pichavant \\ Centre de Recherches sur la Synthèse et Chimie des Minéraux, CNRS, Orléans, France
}

\begin{abstract}
By using recently determined experimental phase equilibria we show that the viscosity of granitic magmas emplaced at upper crustal levels is approximately constant at $\sim 10^{4.5} \mathrm{~Pa} \mathrm{~s}$, irrespective of their temperature and level of emplacement. Magmas crystallizing as granitic plutons are not water-poor and thus not more viscous than their extrusive equivalents. Instead, comparison between pre-eruption magma viscosities of extrusive silicic-intermediate and intrusive granitic magmas shows that the former are on average slightly more viscous. Given the typical strain rates in silicic magma chambers, magma rheological behavior is expected to be dominantly Newtonian, bubbles having a minor rheological influence at depth although exceptions can exist. Thus whether a silicic-intermediate magma is erupted or frozen at depth depends primarily on the rheological properties of surrounding terranes or on external tectonic factors, but not on the rheology of the magma itself. However, preeruptive viscosities of extrusive magmas rarely exceed $10^{6} \mathrm{~Pa} . \mathrm{s}$, which suggests that crystal-melt mushes with higher viscosities cannot leave the magma storage regions beneath volcanoes. The narrow range of viscosities displayed by silicicintermediate magmas results from both the strong control that pressure exerts on volatile solubilities in silicate melts and thermal limitations required to produce acid magmas.

Considerations of the relationships between magma crystallinities, bulk $\mathrm{SiO}_{2}$, and preeruptive melt $\mathrm{H}_{2} \mathrm{O}$ contents show that the higher the melt $\mathrm{H}_{2} \mathrm{O}$ content is the higher the maximum crystallinity that a given magma will be while still being potentially erupted. An empirical correlation is proposed that enables us to estimate preeruptive melt $\mathrm{H}_{2} \mathrm{O}$ contents of erupted magmas by knowing their crystallinity and bulk $\mathrm{SiO}_{2}$.
\end{abstract}

\section{Introduction}

Silicic magmas are often chosen to illustrate the end-member behavior of viscous fluids on Earth, with inferred viscosities that span nearly 10 orders of magnitude $\left(10^{5}-10^{13}\right.$ Pa.s), whereas basalt viscosities cluster tightly around $10^{1}-10^{2} \mathrm{~Pa} . \mathrm{s}$ [e.g., McBirney and Murase, 1984]. Such contrasted behavior is still viewed as a major reason for basalts being easily erupted at the Earth' surface while silicic magmas pond at depth. However, recent studies have shown that from a rheological standpoint, granites behave in much the same way as basalts, yet they are colder by $300^{\circ}-500^{\circ} \mathrm{C}$ [see Wall et al., 1987; Clemens and Mawer, 1992]. They are emplaced at high levels in the crust through fractures, with magma flow rates of $0.01-1 \mathrm{~m} \mathrm{~s}^{-1}$ and with temperatures close to the liquidus when emplaced, filling, in some instances, upper crustal chambers of $\sim 150 \mathrm{~km}^{3}$ within a few years [e.g., Clemens and Mawer, 1992; Scaillet et al., 1996]. Granitic magmas are nevertheless still widely perceived as failed rhyolites. This view implicitly

\footnotetext{
'Now at Institut für Mineralogie, Universität Hannover, Hannover, Germany.

Copyright 1998 by the American Geophysical Union.

Paper number $98 \mathrm{JB} 02469$.

0148-0227/98/98JB-02469\$09.00
}

assumes that the water contents of the magmatic precursors of plutonic rocks are much lower than that of their volcanic counterparts [e.g., Johnson et al., 1994]. Attempts to determine intensive parameters governing the evolution of plutonic rocks through a classical petrological approach give rise to estimates that are, at best, legacies of near-solidus conditions [e.g., Whitney, 1988]. Most of the current viscosity determinations for granitic magmas are thus necessarily fraught with assumptions regarding temperature, melt composition, and crystal content. Early experimental work [Maaloe and Wyllie 1975], though pioneering the use of phase equilibrium studies as a working tool for inferring intensive conditions in the evolution of plutonic rocks, has suffered from the lack of analytical methods for measuring the water content of quenched experimental charges and is thus of little use for constraining the rheological properties of granitic liquids and magmas. This is apparent in the compilation of Clemens [1984] on the water content of silicic-intermediate magmas, where most phase equilibrium studies carried out on plutonic rocks provide only maximum estimates of melt $\mathrm{H}_{2} \mathrm{O}$ contents. More recently, Whitney [1988] reviewed experimental evidence for the water content of granitic magmas and concluded that their $\mathrm{H}_{2} \mathrm{O}$ contents were more likely in the range 2-4 wt \%, although for similar reasons (i.e., lack of analytical tools) the melt $\mathrm{H}_{2} \mathrm{O}$ contents (not to be confused with the magma $\mathrm{H}_{2} \mathrm{O}$ content) could not be better determined. In contrast, recently 
performed phase equilibrium studies have benefited from the analytical improvements made in the past 10 years in the determination of melt $\mathrm{H}_{2} \mathrm{O}$ contents [e.g., Newman et al., 1986; Deloule et al., 1995; Devine et al., 1995]. This enables a more accurate characterization of the rheological properties of experimental phase assemblages and granitic magmas. In parallel, the new analytical tools for measuring the $\mathrm{H}_{2} \mathrm{O}$ content of quenched glasses, together with well-calibrated thermobarometers for the determination of temperature, pressure, and $\mathrm{fO}_{2}$, have also been extensively applied recently to volcanic rocks. The two types of approaches now allow an accurate determination of the major factors controlling magma viscosity (temperature, liquid composition including water content, and crystal content), either, for volcanic systems, in the magma storage zone [e.g., Gardner et al, 1995a] or, for plutonic systems, at the emplacement level of the magmas [e.g., Clemens and Wall, 1981].

In this paper we use recently determined experimental phase equilibria to infer the viscosities of five crustally derived granites during their ascent and emplacement and to compare them to the preeruption melt viscosities of silicic-intermediate extrusive magmas. We show that melt viscosities cluster around $10^{4}-10^{5} \mathrm{~Pa} \mathrm{~s}$ irrespective of the either extrusive or intrusive nature, temperature, and $\mathrm{H}_{2} \mathrm{O}$ content of the magmas.

\section{Method and Rocks Studied}

To constrain the viscosity of silicic plutonic rocks, we use the results obtained from the phase relations recently determined on several granites. The granitic plutons are those of Strathbogie, Watergums (Australia), Manaslu, Gangotri (Himalaya) and Jamon (Brazil) [Clemens and Wall, 1981; Clemens et al, 1986; Scaillet et al., 1995; R. Dall'Agnoll et al., Evolution of A-type granite magmas: an experimental study of the lower proterozoic Jamon granite, eastern Amazonian craton, Brazil, submitted to Journal of Petrology, 1998]. Their $\mathrm{SiO}_{2}$ contents range from 71 to $75 \mathrm{wt} \%$ and the rocks are either peraluminous or metaluminous. They are representative of different types of granitic magmatism although all are formed by partial melting of the continental crust. The experimental studies have constrained the $T-\mathrm{H}_{2} \mathrm{O}_{1 \mathrm{n}}$ melt $(w t \%)$ conditions and crystal content during the emplacement of the magmas, by comparing the experimental phase equilibria with the natural crystallization sequence as deduced from textural observations. All these studies have invariably confirmed the crystal-poor nature of the magmas during emplacement [see Wall et al., 1987], suggesting that fractionation was limited during ascent and hence that magma composition at its emplacement level (where the magma chamber was built) was close to that produced in the partial melting zone. In other words, these magmas were emplaced in a nearly entirely molten state in upper crustal chambers, where crystallization occurred. The most important aspect of the experimental work is that it has confirmed the water-rich nature (3-7 wt $\% \mathrm{H}_{2} \mathrm{O}_{\mathrm{m} \text { mell }}$ ) of the magmas parental to these plutonic rocks. These studies thus represent the best opportunity to quantify the viscosity of granites during at least two major steps of their evolution, ascent, emplacement, and crystallization.

For volcanic rocks we restrict our analysis to rocks whose preeruption conditions have been determined either from phase equilibrium experiments (Mount St. Helens dacite, Fish
Canyon Tuff latite, Spor Mountain rhyolite, El Chichón trachyandesite, Pinatubo dacite, and Mt. Pelée andesite) or from the direct measurement of the $\mathrm{H}_{2} \mathrm{O}$ content of melt inclusions, and FeTi oxides for temperature (Bishop Tuff, Cerro Toledo, Lower Bandelier, Taupo Rhyolite, Crater Lake, Pine Grove, Katmai, Fantale, Inyo Dome, and Krakatau). For the Bishop Tuff several recent studies have determined its preeruptive melt $\mathrm{H}_{2} \mathrm{O}$ content and variation during the main eruptive cycles [Anderson et al., 1989; Skirius et al., 1990; Dunbar and Hervig, 1992a; Wallace et al., 1995]. In this study we use melt $\mathrm{H}_{2} \mathrm{O}$ contents given by Anderson et al. [1989], Skirius et al. [1990] and Wallace et al. [1995], yet to avoid redundancy, only those of Skirius et al. are reported in table 1 and in figures 1-4. For cases where the determined $\mathrm{H}_{2} \mathrm{O}$ contents of melt inclusions analyzed in a given sample display a dispersion much larger than the analytical uncertainty (for instance, Cerro Toledo) [Stix and Layne, 1996], although the anhydrous major element composition of the glass inclusions remains constant, only the highest values were used for the viscosity calculations. In doing so we assume that $\mathrm{H}_{2} \mathrm{O}$-poor glass inclusions were affected by syneruptive to posteruptive $\mathrm{H}_{2} \mathrm{O}$ loss, an assumption supported by results obtained from the study of Pinatubo melt inclusions [Westrich and Gerlach, 1992; Rutherford and Devine, 1996; Gerlach et al., 1996; Scallet and Evans, 1998]. Apart from Macusani, volcanic rocks for which preeruptive $\mathrm{H}_{2} \mathrm{O}$ contents have been inferred only through mineral-fluid or mineral-melt equilibria were not considered here. The reason for this is that such an approach often yields a poorly constrained range of melt $\mathrm{H}_{2} \mathrm{O}$ contents given the uncertainties in experimental calibrations and solution models. These problems, added to the fact that reported temperatures may vary by more than $100^{\circ} \mathrm{C}$, make it difficult to chose the appropriate $T-\mathrm{H}_{2} \mathrm{O}_{\text {in ment }}(w \mathrm{t} \%)$ values for calculating melt viscosities. The Macusani volcanics are considered here because pre-eruptive melt $\mathrm{H}_{2} \mathrm{O}$ content and temperature are particularly well constrained [Pichavant et al., $1988 \mathrm{a}, \mathrm{b}]$ and allow the database to be extended toward temperatures below $650^{\circ} \mathrm{C}$ (Table 1). The compositional spectrum covered by the volcanic rocks is larger than that for the plutonics, with bulk $\mathrm{SiO}_{2}$ contents ranging from trachyandesitic to rhyolitic $(57-78 \mathrm{wt} \%)$. The data set includes peralkaline, metaluminous, and peraluminous compositions, which are associated with extensional (peralkaline) to compressional (peraluminous) regional tectonic stress regimes. Although examples of explosive eruptions largely dominate the data set, effusive volcanic rocks are also represented (Inyo Dome). For the explosive eruptions the samples represent a wide range in ejected masses, with volumes in dense rock equivalent ranging from $0.1 \mathrm{~km}^{3}$ (Mt. Pelée) up to $3000 \mathrm{~km}^{3}$ (Fish Canyon Tuff). Taken together, the plutonic and volcanic rocks represent a range of intermediate to silicic magmas involved in a large variety of tectonic settings, which ensures that our conclusions are of general validity.

\section{Viscosity Calculations}

For metaluminous felsic melts that fit the following chemical criteria (wt \%), we use the empirical equation of Hess and Dingwell [1996]: $\mathrm{SiO}_{2}=73.2-78.6 ; \mathrm{CaO}+\mathrm{MgO}+\mathrm{FeO}=0$-2.34; $\left.\left(2 \mathrm{Na}+2 \mathrm{~K}+\mathrm{Mg}+\mathrm{Ca}+\mathrm{Fe}^{2+}\right) /\left(2 \mathrm{Al}+2 \mathrm{Fe}^{3+}\right)=0.93-1.02\right)$. For 
Table 1. Calculated Melt and Magma Viscosities for Natural Intermediate to Silicic Plutonic and Volcanic Rocks

\begin{tabular}{|c|c|c|c|c|c|c|c|c|c|}
\hline Rock & $\begin{array}{c}\mathrm{SiO}_{2} \\
\text { Magma, } \\
\text { wt \% }\end{array}$ & $\begin{array}{l}\mathrm{SiO}_{2} \\
\text { Melt, } \\
\text { wt \% } \\
\end{array}$ & $\begin{array}{l}\text { Crystals, } \\
\text { \% volume }\end{array}$ & $\begin{array}{l}T, \\
{ }^{\circ} \mathrm{C} \\
\end{array}$ & $\begin{array}{l}\mathrm{H}_{2} \mathrm{O} \\
\text { Melt, } \\
\text { wt \% } \\
\end{array}$ & $\begin{array}{c}\log \eta \\
\text { Melt, } \\
\text { Pa s } \\
\end{array}$ & $\begin{array}{c}\log \eta^{\mathrm{a}} \\
\text { Magma, } \\
\text { Pa s }\end{array}$ & Method $^{b}$ & References ${ }^{c}$ \\
\hline \multicolumn{10}{|c|}{ Plutonics } \\
\hline Gangotri & 72.9 & 72.9 & $<10$ & 700 & 70 & 4.2 & 44 & $\operatorname{Exp}, \mathrm{Sc}$ & 1 \\
\hline Manaslu & 73.0 & 73.0 & $<10$ & 750 & 5.5 & 5.0 & 5.2 & Exp, Sc & 1 \\
\hline Jamon & 71.5 & 71.5 & $<10$ & 920 & 45 & 4.1 & 4.2 & Exp, Sh & 2 \\
\hline Stratboghie & 70.4 & 70.4 & $<10$ & 850 & 4.5 & 4.6 & 4.8 & Exp, Sh & 3 \\
\hline Watergums & 74.5 & 74.5 & $<10$ & 900 & 3.5 & 4.7 & 4.9 & Exp, Sh & 4 \\
\hline \multicolumn{10}{|c|}{ Volcanics } \\
\hline Fantale & 71.0 & 71.0 & 14 & 800 & 4.6 & 3.9 & 4.2 & IR, Sh & 5 \\
\hline Fantale & 71.0 & 71.0 & 14 & 800 & 49 & 37 & 4.0 & IR, Sh & 5 \\
\hline Pine Grove & 75.1 & 76.4 & 32 & 675 & 7.1 & 53 & 5.8 & IR, HD & 6,7 \\
\hline Pinatubo & 64.0 & 78.3 & 47 & 780 & 6.4 & 4.5 & 5.7 & Exp, IR, IP, HD & $8,9,10$ \\
\hline El Chichón & 57.2 & 71.4 & 57 & 800 & 5.0 & 4.5 & 7.2 & Exp, Sh & 11 \\
\hline Crater Lake & 73.0 & 73.0 & 10 & 885 & 3.9 & 4.7 & 4.9 & IR, Sh & 12 \\
\hline Crater Lake & 73.0 & 73.0 & 10 & 885 & 4.7 & 4.2 & 4.4 & IR, Sh & 12 \\
\hline St. Helens-1980 & 62.8 & 73.5 & 37 & 930 & 4.6 & 3.7 & 4.4 & Exp, VDB, Sh & 13 \\
\hline St. Helens-T & 63.2 & 70.2 & 31 & 893 & 4.6 & 3.8 & 4.3 & Exp, Sh & 14 \\
\hline St. Helens-Wn & 67.2 & 74.8 & 27 & 847 & 4.8 & 3.8 & 5.1 & Exp, Sh & 14 \\
\hline St. Helens-Bi & 64.1 & 72.8 & 41 & 913 & 3.7 & 4.5 & 5.3 & Exp, Sh & 14 \\
\hline St. Helens-Pu & 63.3 & 74.3 & 46 & 870 & 43 & 4.6 & 5.7 & Exp, Sh & 14 \\
\hline St. Helens-Ye & 65.5 & 75.6 & 40 & 795 & 56 & 4.5 & 5.3 & Exp, Sh & 14 \\
\hline St. Helens-Yn & 65.9 & 75.5 & 35 & 768 & 6.5 & 4.4 & 5.0 & Exp, Sh & 14 \\
\hline St. Helens-Yn & 65.8 & 74.8 & 32 & 790 & 6.3 & 4.2 & 4.7 & Exp, Sh & 14 \\
\hline Fish Canyon & 64.4 & 77.1 & 40 & 760 & 5.0 & 5.2 & 6.0 & Exp, HD & 15 \\
\hline Spor Mountain & 72.9 & 72.9 & 30 & 735 & 6.0 & 4.8 & 5.6 & Exp, HD & 16 \\
\hline Katmai Andesite & 58.6 & 74.3 & 25 & 990 & 1.0 & 4.1 & 4.7 & IR, IP, Sh & 17,18 \\
\hline Katmai Dacite & 64.6 & 77.4 & 10 & 950 & 2.8 & 4.5 & 4.6 & IR, IP, HD & 19,18 \\
\hline Katmai Rhyolite & 77.4 & 78.5 & 1 & 900 & 4.0 & 4.4 & 4.4 & IR, IP, HD & 19,18 \\
\hline Inyo Dome & 71.5 & 71.5 & 5 & 897 & 3.9 & 4.5 & 4.5 & $\mathrm{IP}, \mathrm{Sh}$ & 20,18 \\
\hline Inyo Dome & 73.7 & 73.7 & 5 & 874 & 4.3 & 4.5 & 4.5 & IP, $\mathrm{HD}$ & 20,18 \\
\hline Taupo Plinian & 74.0 & 76.0 & 5 & 850 & 43 & 4.9 & 5.0 & IP, Sh & 21,22 \\
\hline Taupo Okaia & 74.0 & 76.0 & 13 & 798 & 5.9 & 4.4 & 4.6 & IP, Sh & 21,22 \\
\hline Taupo Hapete & 74.0 & 76.0 & 5 & 839 & 43 & 5.0 & 5.1 & IP, Sh & 21,22 \\
\hline Bishop Plinian & 77.0 & 77.0 & 7 & 710 & 6.3 & 5.2 & 5.3 & IR, HD & 23,18 \\
\hline Bishop Chidago & 77.0 & 77.0 & 10 & 720 & 6.5 & 5.0 & 5.2 & IR, HD & 23,18 \\
\hline Bishop Mono & 77.0 & 77.0 & 22 & 790 & 4.2 & 5.2 & 5.7 & IR, HD & 23,18 \\
\hline Cerro Toledo-15-8 & 72.0 & 72.0 & $<5$ & 813 & 5.3 & 4.6 & 4.7 & IP, HD & 24,25 \\
\hline Cerro Toledo-15-9 & 73.4 & 73.4 & $<5$ & 813 & 68 & 4.2 & 4.3 & IP, HD & 24,25 \\
\hline Cerro Toledo-15-11 & 73.0 & 73.0 & $<5$ & 777 & 6.8 & 4.4 & 4.5 & IP, HD & 24,25 \\
\hline Cerro Toledo-6-8 & 73.0 & 73.0 & $<5$ & 697 & 6.7 & 5.2 & 5.3 & IP, HD & 24,25 \\
\hline Bandelier Upper & 73.1 & 73.1 & $<5$ & 697 & 6.2 & 5.4 & 5.5 & IP, HD & 24,26 \\
\hline Mt. Pelée & 610 & 75.0 & 50 & 875 & 5.5 & 3.9 & 5.8 & Exp, IR, Sh & 27 \\
\hline Montserrat & 59.0 & 77.6 & 40 & 830 & 47 & 4.7 & 5.5 & Exp, IR, Sh & 28,29 \\
\hline Krakatau Rhyodac. & 69.5 & 72.0 & 10 & 885 & 40 & 4.4 & 4.6 & VBD, Sh & 30 \\
\hline Macusani & 73.0 & 72.0 & 45 & 635 & 72 & 4.9 & 5.9 & Calc, Sc & 31 \\
\hline
\end{tabular}

For the Spor Mountain and Macusani rhyolites the $\mathrm{H}_{2} \mathrm{O}$ contents include $\mathrm{F}, \mathrm{B}$, and $\mathrm{Li}$

a Magma viscosity calculated using the melt viscosity and the Eisnstein-Roscoe relationship as modified by Marsh [1981] for crystal contents up to $30 \%$ volume from equation (2) for higher crystal contents.

$\mathrm{b}_{\mathrm{Method}}$ of $\mathrm{H}_{2} \mathrm{O}$ determination Exp, experimental phase equilibria; IR, infrared spectroscopy; IP, ion probe, VDB, volatile by difference; Calc., calculated through mineral equilibria. The model used to calculate the melt viscosity is given as follows: Sc, Scaillet et al. [1996]; Sh, Shaw [1972]; or HD, Hess and Dingwell [1996].

peraluminous leucogranite ones the equation of Scaillet et al. [1996], experimentally calibrated on a natural strongly peraluminous melt, is used. The model of Shaw [1972] was used to calculate silicate melt viscosities of all remaining melts because (1) it is the only one that explicitly takes into account the liquid composition in hydrous systems, and (2) its experimental range of calibration, in terms of melt $\mathrm{H}_{2} \mathrm{O}$ content and temperature, is similar to that relevant for natural granites and for most silicic erupted magmas, as deduced from the studies mentioned in section 2. Although recent work has shown that the Shaw model may either underestimate or overestimate melt viscosities at low water contents [Stein and Spera, 1993; Schulze et al., 1996; Dingwell et al., 1996;
Baker, 1996], good agreement between experimental and calculated melt viscosities is observed in the range of melt $\mathrm{H}_{2} \mathrm{O}$ contents of interest for the present study (mainly, 3-7 wt \% $\mathrm{H}_{2} \mathrm{O}$ ), differences barely exceeding $1 \mathrm{log}$ unit. Although low melt $\mathrm{H}_{2} \mathrm{O}$ contents do occur in the evolution of magmatic rocks, they are attained mainly in volcanic contexts, during the final stages of degassing. All these processes are not considered in this paper (see, for instance, Dingwell et al. [1996]) where only preeruption conditions are taken into account.

It is well established that silicate melt viscosities depend, among other factors, on the strain rate, viscosities at high strain rates exhibiting significant departure from Newtonian behavior [e.g., Webb and Dingwell, 1990; Dingwell and 
$W e b b, 1990 ;$ Bottinga, 1994]. The strain rates required to observe non-Newtonian behavior in silicate melts correspond to timescales 3 orders of magnitude lower than the structural relaxation timescale $\tau$ for the melt [Webb and Dingwell, 1990], the latter parameter being related to the relaxed shear viscosity $\eta_{\text {melt }}$ by the Maxwell relation:

$$
\tau=\eta_{\text {melt }} / G_{\infty}
$$

$G_{\infty}$ being the infinite frequency shear modulus of the melt [see Dingwell and $W e b b, 1990]$. Given that $G_{\infty}$ is constant for most silicate melts $\left(\log G_{\infty}=10 \pm 0.5 \mathrm{~Pa}\right)$ [Dingwell and Webb , 1990], variations in the relaxation time arise predominantly from melt viscosity. For the range of melt viscosities found in this paper (see below), the structural relaxation time is of the order of $10^{-5}-10^{-6} \mathrm{~s}$. Estimated convective rates in silicic magma chambers are of the order of $10^{-8} \mathrm{~s}^{-1}$ [see Spera et al., 1988], which is largely below the threshold for the onset of nonNewtonian viscosity ( $3 \log$ units below the $\log$ of the relaxed strain rate $\left.\left(1 / \tau=10^{5} \mathrm{~s}^{-1}\right)\right)$. In addition, there have been suggestions based both on analogical [e.g., Brandeis and Marsh, 1989] and numerical [e.g., Brandeis and Jaupart, 1986] modeling that convection in silicic magma chambers is weak or nonexistent, convective motions virtually ceasing when crystallization starts [Marsh, 1989]. These facts suggest that the melt phase obeys dominantly a Newtonian behavior under pre-eruption conditions.

For calculating magma viscosities having less than $30 \%$ (volume) of crystals we use the Einstein-Roscoe relationship, as modified by Marsh [1981]. Recent studies have shown that this empirical relation holds well at low crystal contents [Pinkerton and Stevenson, 1992; Lejeune and Richet, 1995]. At higher crystal contents, however, this relation is no longer valid [see Pinkerton and Stevenson, 1992], and we use the following equation, as recommended by Dingwell et al [1993]:

$$
\eta_{\text {magma }}=\eta_{\text {melt }}\left\{1+0.75\left[\left(f / f_{m}\right) /\left(1-f / f_{m}\right]\right\}^{2}\right.
$$

where $\eta_{\text {magma }}$ and $\eta_{\text {melt }}$ are the viscosities of the magma and the melt, respectively, $f$ is the volume fraction of crystal, and $f_{m}$ is the concentration of crystals beyond which the magma has an "infinite" viscosity. Following Marsh [1981] and Pinkerton and Stevenson [1992] we have chosen a value of 0.6 for $f_{m}$. Strictly, $f_{m}$ is a function of crystal size distribution, which is unknown for the magmas considered in this report, and thus we have taken the value for a monodisperse suspension. Equation (2) gives relaxed shear viscosities, i.e., the viscosity at low strain rates, in keeping with the inference of low strain rates at work in silicic magma chambers.

In addition to crystals, magmas can contain bubbles. Recent studies of silicic- intermediate arc magmas using either trace element behavior [Wallace et al., 1995] or sulfur yields associated with explosive eruptions [Scaillet et al., 1998] yielded preeruption fluid contents that generally did not exceed $5 \mathrm{wt} \%$, with fluids having $\mathrm{H}_{2} \mathrm{O}$-rich compositions. For $\mathrm{H}_{2} \mathrm{O}$ densities in the range $800^{\circ}-900^{\circ} \mathrm{C}$ and $200-300 \mathrm{MPa}$, such an amount translates into a fluid volume fraction of $10 \%$. As with crystals, the effect of bubbles on magma viscosity depends on size distribution and strain rate, among other parameters (i.e., capillary number and viscosity ratio) [Spera et al., 1988; Stein and Spera, 1992; Bagdassarov and Dingwell, 1992, 1993]. The presence of bubbles introduces an additional relaxation time, related to the response of bubbles to viscous stresses [Bagdassarov and Dingwell, 1992, 1993]. This relaxation time $\tau_{b}$ is related to the melt viscosity and bubble radius $R$ :

$$
\tau_{b}=\eta_{\text {melt }} R / \sigma
$$

$\sigma$ being the surface tension. If the strain rate is greater than $\tau_{b}{ }^{-1}$, bubbles behave as rigid particles, like crystals, and the viscosity of the bubble-bearing magma is increased [Stein and Spera, 1992]. Inversely, when the strain rate is slow (i.e., in magma chambers), bubbles will deform viscously and the magma viscosity is decreased [Bagdassarov and Dingwell, 1993]. There are, obviously, no direct measurements of $R$ at preeruption conditions (excluding fluid inclusions trapped in melt inclusions or crystals). Crystallization experiments of natural magmas saturated with $\mathrm{H}_{2} \mathrm{O}-\mathrm{CO}_{2}\left( \pm \mathrm{H}_{2} \mathrm{~S}\right)$ fluids aimed at defining preeruption conditions generally give bubble radii in the range 10-100 $\mu \mathrm{m}$ [e.g., Scaillet and Evans, 1998]. These are probably minimum values since the timescale of laboratory experiments is likely to be much shorter than the residence time of magmas in the storage region, during which bubbles can coalesce and thus increase in size (but note that large deformations will have the opposite effect; Stein and Spera [1992]). Taking an average melt viscosity of $10^{5} \mathrm{~Pa} \mathrm{~S}$, a surface tension of $0.1 \mathrm{~N} \mathrm{~m}^{-1}$ [Bagdassarov and Dingwell, 1992] , and $R=100 \mu \mathrm{m}$ yields $\tau_{b}=100 \mathrm{~s}$ whose inverse is $10^{-2} \mathrm{~s}^{-1}$. This is significantly higher than strain rates in silicic magma chambers, so that bubble-bearing magmas can be predicted to have lower viscosities than bubble-free ones. The experiments performed by Bagdassarov and Dingwell [1992] on a viscous $\left(\sim 10^{9} \mathrm{~Pa}\right.$ s) rhyolitic melt at low strain rates $\left(10^{-5}-10^{-7} \mathrm{~s}^{-1}\right)$ yielded the following relationship:

$$
\eta_{\text {magma }}=\eta_{\text {melt }}[1 /(1+24.4 f)]
$$

where $f$ is the volume fraction of bubbles. Use of (4), together with the estimate of preeruption fluid contents, results in a maximum decrease of the magma viscosity by a factor of 3 . This lowering effect of bubbles upon magma viscosity has been shown to hold also in melt+crystal+bubble suspensions [Bagdassarov et al., 1994], the presence of bubbles counteracting that of solid particles. For instance, a magma having $16 \%$ bubbles and $16 \%$ sapphire spheres has a shear viscosity almost identical to that of the melt phase alone. Although strain rates in silicic magma chambers are expected to be low, it is instructive to calculate how much magma viscosity will be affected by bubbles under high strain rates. Stein and Spera [1992] have obtained the following empirical equation for calculating the viscosity of magmatic emulsions with a melt viscosity of $10^{5} \mathrm{~Pa} \mathrm{~s}$, and low gas content $(<7 \%$ vol), at relatively high strain rates $\left(0.06-7 \mathrm{~s}^{-1}\right)$ :

$$
\eta_{\text {magma }}=\eta_{\text {melt }}(1+13.1 f)
$$

where $\eta_{\text {magma }}$ stands for the viscosity of melt+bubbles and $f$ is the volume fraction of bubbles. Equation (5) shows that under the storage conditions of silicic magmas, high strain rates will rise by a factor of 2 the magma viscosity. Altogether, these considerations suggest that as far as preeruption conditions are considered, bubbles play a minor role in magma rheology when compared, for example, to that played by variations in crystal contents of erupted magmas $(0-60 \%)$ or to the viscosity variations arising from changes in melt $\mathrm{H}_{2} \mathrm{O}$ contents. Accordingly, unless otherwise stated, magma viscosities reported here do not take into account the role of bubbles. In 
view of the above calculations and considering the possible range of fluid content found in natural magmas (see above), the melt viscosities reported in this work can therefore be considered to be accurate to within a factor of 3 .

\section{Melt and Magma Viscosities Before Uprise}

The calculated melt and magma viscosities of the rocks used in this study, together with the main compositional features necessary for the calculations, are listed in Table 1. In Figure 1 the melt $\mathrm{H}_{2} \mathrm{O}$ contents of granitic magmas are plotted against the temperature, both variables being taken for conditions prevailing during magma emplacement in the upper crust. A similar plot is constructed for the preeruption $T-\mathrm{H}_{2} \mathrm{O}$ (wt \%) conditions of the volcanic rocks. The overall pattern is a nearly linear inverse relationship between $T$ and $\mathrm{H}_{2} \mathrm{O}$, the drier magmas being the hottest. No difference appears between plutonic and volcanic rocks. In Figure 2 the melt viscosities of granitic magmas are plotted against the emplacement temperature of the magma and compared to the preeruptive - melt viscosities of the volcanic rocks. Again, both plutonic and volcanic melt viscosities lie on a single horizontal trend over more than $350^{\circ} \mathrm{C}$, virtually spanning the entire temperature range covered by silicic magmas [Ghiorso and Sack, 1991]. It is worth mentioning that the Macusani volcanics, whose estimated preeruptive temperature and melt $\mathrm{H}_{2} \mathrm{O}$ content are $635^{\circ} \mathrm{C}$ and $5 \mathrm{wt} \%$, respectively [Pichavant et al, 1988a,b], give a liquid viscosity of 7.2 unit $\log \mathrm{Pa} . \mathrm{s}$; that is, they would plot well above the general trend. However, if the effects on melt viscosity of volatiles other than $\mathrm{H}_{2} \mathrm{O}(\mathrm{F}, \mathrm{Li}$, and $\mathrm{B})$ are considered [Dingwell et al., 1992; Baker and Vaillancourt, 1995] and assuming that these effects add up, the preeruptive melt viscosity for the Macusani volcanics is $4.89 \log$ unit $\mathrm{Pa} \mathrm{s}$, in good agreement with the calculated viscosities for other less evolved felsic magmas. A similar rationale can be applied to the Spor Mountain rhyolite in which the additive effects of $\mathrm{H}_{2} \mathrm{O}$ and $F$ result in a preeruption viscosity similar to other volcanic rocks as well (Table 1). These examples illustrate the fact that the pattern of Figure 2 is not specific to magmas in which the dominant volatile is $\mathrm{H}_{2} \mathrm{O}$ but also applies to those highly enriched in halogens or other volatile elements. Conversely, it suggests that melts enriched in volatiles other

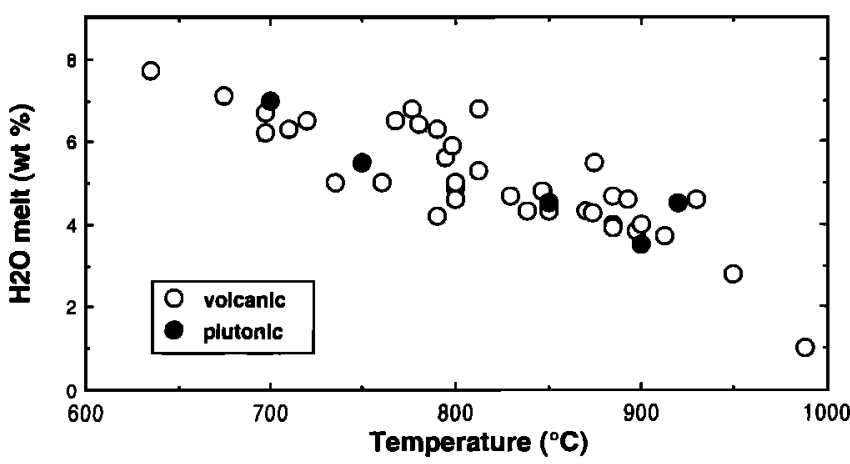

Figure 1. Relationship between temperature and melt $\mathrm{H}_{2} \mathrm{O}$ content for both plutonic (solid circles) and volcanic (open circles) rocks. For the plutonic rocks the conditions correspond to magma emplacement, and for volcanic rocks the conditions correspond to preeruption conditions. Source of data is given in Table 1 .

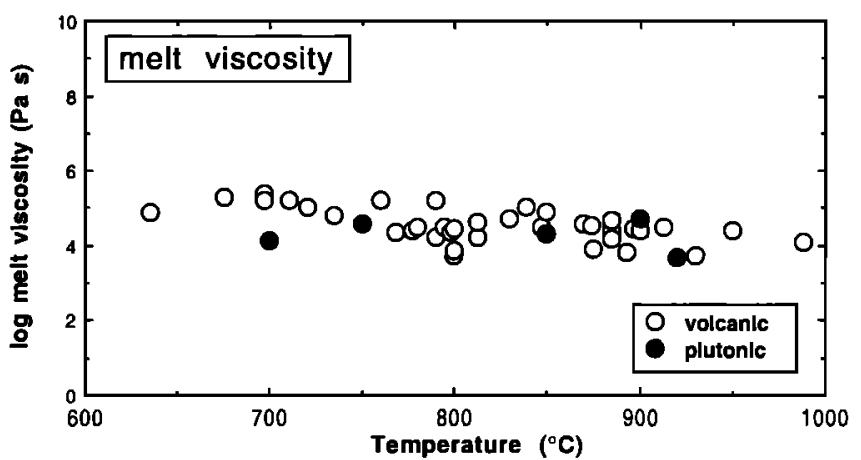

Figure 2. Melt viscosities for granitic magmas (solid circles), plotted as a function of their emplacement temperature and compared to the preeruption melt viscosities of volcanic rocks (open circles) listed in Table 1. For all granites the melt composition used in the viscosity calculation is that of the bulk composition used in the phase equilibrium studies. See text and Table 1 for details on viscosity calculations.

than water will not segregate from their source earlier (i.e., at lower viscosity) than those containing only dissolved water. The average value of melt viscosity for the whole data set is log $\eta_{\text {melt }}=4.5 \pm 0.5$ (Pa s).

The experimental work indicates that magmas parental to the plutonic rocks were all emplaced at near liquidus conditions, with crystal contents less than $10 \mathrm{wt} \%$ and thus that melt viscosities were close to magma viscosities. In contrast, preeruptive crystallinities for volcanic rocks vary from 0 to $60 \%$, displaying a clear inverse relationship with bulk $\mathrm{SiO}_{2}$ content (Figure 3). This relationship could partly reflect the increase in incubation time for the onset of crystallization in silicate melts as $\mathrm{SiO}_{2}$ increases. Numerical modeling indicates, however, that crystallization in large magma chambers occurs under quasi-equilibrium conditions with small undercooling, except near the very borders at early stages of the intrusion [Brandeis et al., 1984]. Given that the volcanic rocks used in this study come from magma chambers of moderate to large sizes ( 1 to several hundred $\mathrm{km}^{3}$, the volume of erupted magma representing on average $10-20 \%$ of the magma chamber), it is likely that the thermal regime in their storage region was characterized by slow cooling rates and thus that the relationship of Figure 3 is not due to kinetic effects. Therefore, given that both intrusive and extrusive magmas display similar melt viscosities, if the effects of crystals are taken into account, the viscosities of silicic volcanic rocks are on average slightly higher than that of their granitic counterparts (Figure 4). Nevertheless, apart from a single outlier (El Chichón trachyandesite), volcanic rock viscosities plot in a restricted viscosity range, $10^{4}-10^{6} \mathrm{~Pa} \mathrm{~s}$. This suggests that magmas more viscous than $10^{6} \mathrm{~Pa} s$ cannot leave their host chamber but instead freeze at depth. This does not preclude silicic magmas from reaching higher viscosities, however, but highly viscous conditions are likely to be attained only during the last stages of magma ascent and degassing [e.g., Dingwell et al., 1996]. Although magma viscosities are less clustered than melt viscosities, the general pattern with temperature variation is again flat, which indicates that hot magmas are not erupted more easily than cold ones. Our analysis therefore suggests that in many, if not all, instances the preeruption melt and magma viscosities are at, or below, $10^{4.5}$ and $10^{6} \mathrm{~Pa} \mathrm{~s}$, respectively. One apparent exception to this rule is provided 

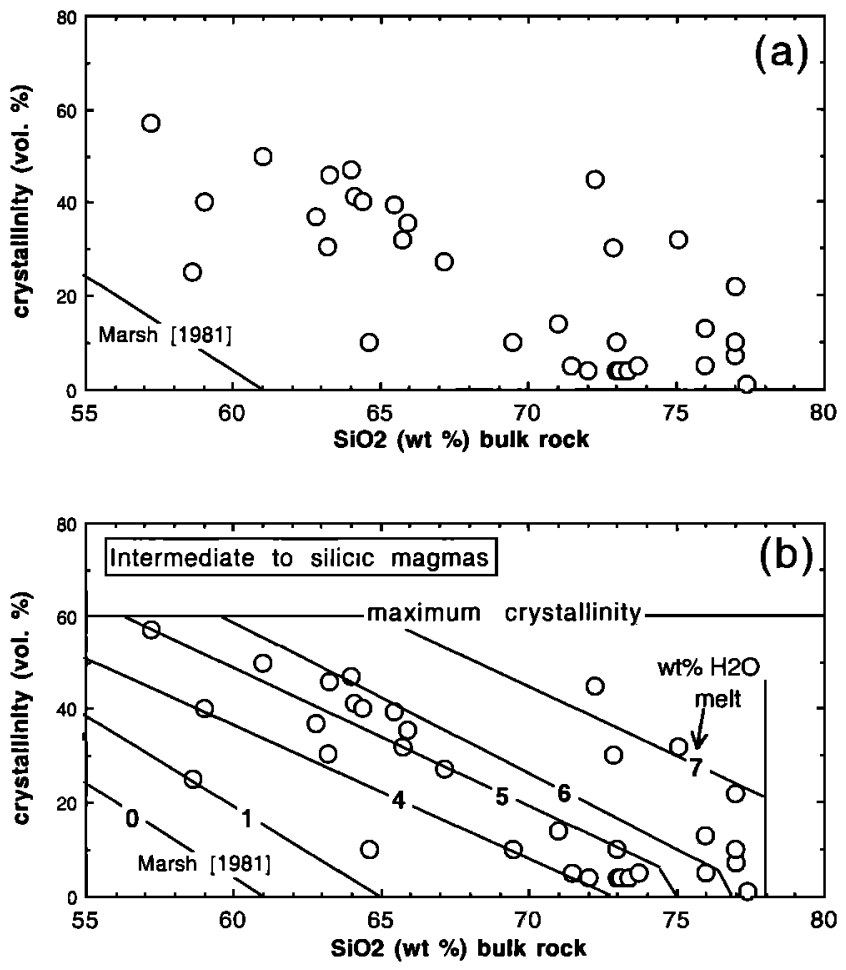

Figure 3. Relationship between magma crystallınity and bulk rock $\mathrm{SiO}_{2}$ for the volcanic rocks of Table 1 , including (a) a plot of the raw data together with the Aleutian lavas trend obtained by Marsh [1981] and (b) the same diagram countoured with lines of isomelt $\mathrm{H}_{2} \mathrm{O}$ contents. All fits are handmade best estimates.

by the El Chichón magma, whose crystal content is close to that at which the magna reaches the solid behavior field. The calculated magma viscosity is more than 1 order of magnitude higher relative to other magmas and, at such high crystal content, magmas can be anticipated to also have a significant yield strength [Pinkerton and Stevenson, 1992]. Nevertheless, this magma has been erupted, and the eruption was of Plinian type. Interestingly, the restored preeruption fluid content of this magma ranges between 8 and $26 \mathrm{wt} \%$, depending on the $\mathrm{CO}_{2}-\mathrm{SO}_{2}$ ratio used [Scaillet et al., 1998], which implies that the volume fraction of the fluid was $\sim 20-50 \%$ of the scavenged part of the magma chamber. Considering the role of bubbles on magma rheology as summarized above, we tentatively suggest that the eruption of El Chichón magma was made possible, or at least greatly facilitated, by the large volume of the fluid phase. Specifically, the experimental results of Bagdassarov et al. [1994] on the effect of bubbles predict that the viscosity of E] Chichón magma is only marginally different from that of the melt phase alone, falling well within the range displayed by the other magmas (Table 1). Finally, though in some instances a relation between eruption intensity and magma viscosity has been clearly established (Mount St. Helens) [Gardner et al. 1995a], no correlation between magma viscosity and eruption volume, or any other parameter, was found.

\section{Inferring Preeruptive Melt $\mathrm{H}_{2} \mathrm{O}$ Contents From Crystallinity}

The relationship between crystallinity and bulk $\mathrm{SiO}_{2}$ (Figure 3) is qualitatively similar to that obtained by Marsh
[1981] for a series of basaltic-andesitic lavas erupted from the Aleutians volcanic center of Atka. Both trends are parallel, the one obtained here being displaced toward higher $\mathrm{SiO}_{2}$ content (Figure 3). In both cases, volcanic rocks with more than 55$60 \%$ crystals are not found, an observation that suggests, as Marsh noted, that there is a locking point, characterized by a critical crystallinity, beyond which magma viscosity increases so dramatically that it behaves essentially as a solid, a proposal corroborated by experimental data [e.g., Pinkerton and Stevenson, 1992; Lejeune and Richet, 1995]. In his analysis of the Aleutians lavas, Marsh derived a value of $10^{4.6}$ $\mathrm{Pa} \mathbf{s}$ for this viscosity threshold. This value is lower by $0.5 \log$ units than the average magma viscosity obtained in this study for volcanic rocks $\left(\log \eta_{\text {magma }}=5.1 \pm 0.7 \mathrm{~Pa} \mathrm{~s}\right.$ ). However, although the magmatic $\mathrm{H}_{2} \mathrm{O}$ contents were not determined, nearly dry conditions $(<1 \mathrm{wt} \%)$ were inferred for the Aleutian lavas [Marsh, 1981], as opposed to the volcanic rocks presented here whose average melt $\mathrm{H}_{2} \mathrm{O}$ content is $\sim 4-5$ wt \%. The two samples lying in between the Aleutian lavas trend and the one obtained here are the andesite and dacite erupted at Katmai, whose water contents are among the lowest of the data set, 1 and $2.8 \mathrm{wt} \%$, respectively. Conversely, the point plotting well above the general trend corresponds to the volcanic rock richest in water, with 7.1 wt \% dissolved $\mathrm{H}_{2} \mathrm{O}$ (Pine Grove). Thus we confirm the prediction of Marsh that water increases the critical crystallinity at a given $\mathrm{SiO}_{2}$ content. In other words, magmas rich in water can be erupted at a higher crystallinity than those poor in $\mathrm{H}_{2} \mathrm{O}$. As proposed by Marsh, the relationship between bulk $\mathrm{SiO}_{2}$ content and magma crystallinity can be used in a quantitative way to infer preeruptive melt $\mathrm{H}_{2} \mathrm{O}$ contents. A generalization of his model has been attempted with our data set and is shown in Figure $3 b$, where the diagram of Figure $3 a$ is contoured with lines of constant melt $\mathrm{H}_{2} \mathrm{O}$ contents. All correlations were assumed to be linear, yet some curvatures probably occur at both ends of the trends. Most of the previous analyses ignore the possible role of bubbles. The overall coherent trend obtained does suggest, however, that in most instances the gas phase abundance is too low to have any appreciable effect on magma rheology under preeruption conditions, as previously argued. Nevertheless, not all the volcanic rocks conform to the lines of isomelt $\mathrm{H}_{2} \mathrm{O}$ content, in particular in the high $\mathrm{SiO}_{2}$ range. For instance, the Mono unit of the Bishop Tuff is clearly off the general trend (Table 1). Owing to the lack of precise preeruptive temperature constraints, the Lower Bandelier Tuffs

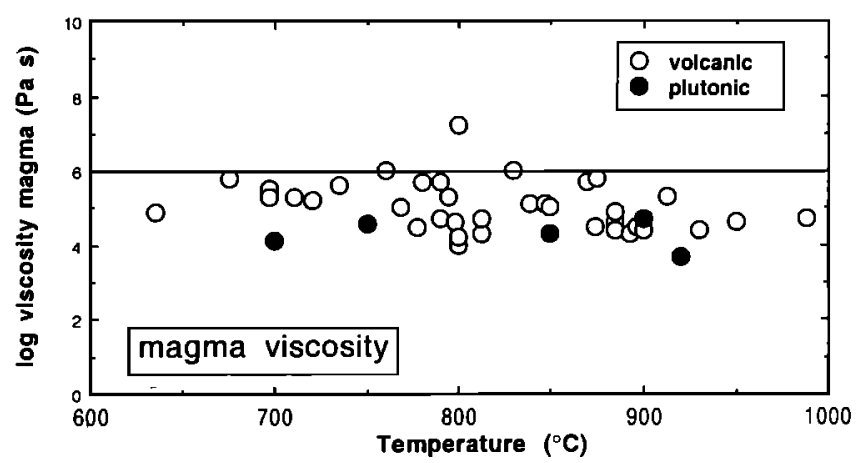

Figure 4. Magma viscosities versus temperature for the plutonic (solid circles) and volcanic (open circles) rocks listed in Table 1 . Note that plutonic rocks are on average slightly less viscous than volcanic ones. 
analyzed by Dunbar and Hervig [1992b] could not be used in the present study, but some of the samples would plot in the same area as the Mono lobe. Although, as illustrated by El Chichón, a high amount of fluid could explain the off position of these high-silica rhyolites, the restored fluid content of the Mono unit is not abnormally high ( $<5 \mathrm{wt} \%$ ) [Wallace et al., 1995]. This lack of correlation may thus reflect a specific characteristic of the large-magnitude volcanic events that gives rise to ignimbrite deposits, with eruptive dynamics fundamentally different from those of smaller eruptions. It is possible that the locking point rule does not hold for certain eruptions of particularly large magnitude. However, not all ignimbrites plot out off the trends, as exemplified by the Fish Canyon Tuff, one of the largest known ignimbrite deposits that fits well with other eruptive events. Clearly, future work will improve the quality of the fit between crystallinity, bulk $\mathrm{SiO}_{2}$, and melt $\mathrm{H}_{2} \mathrm{O}$ content, but we stress that such a diagram (Figure 3) is useful for a first-order estimation of preeruptive melt $\mathrm{H}_{2} \mathrm{O}$ contents of erupted magmas, especially those ejected during eruptions of small to moderate magnitude.

\section{Dikes, Diapirs, and Emplacement Levels}

The rather low viscosities found in this study are consistent with the recent proposal that felsic magma migration occurs through dikes rather than via diapirs [Clemens and Mawer, 1992; Petford et al., 1993]. Emerman and Marret [1990] have shown that the mode of ascent of magmas (as either a dike or a diapir) can be estimated from the following dimensionless parameter:

$$
\lambda=\eta_{\text {magma }} c / d \Delta \sigma
$$

where $c$ is the speed of propagation, $d$ is the difference between the depth at which deviatoric stress becomes significant and the depth of final emplacement, and $\Delta \sigma$ is the difference between the least compressive stress (horizontal for dike emplacement) and the other horizontal principal stresses. This relation evaluates the time needed to reorientate a dike relative to its rate of propagation. If $\lambda$ is much lower than 1 , then the magma will propagate upward as a dike without suffering significant reorientation due to the external stress field. Taking $\Delta \sigma=10$ $\mathrm{MPa}, d=10,000 \mathrm{~m}, c=1 \mathrm{~m} \mathrm{~s}^{-1}$, and $\eta_{\text {magma }}=10^{4.5} \mathrm{~Pa} \mathrm{~s}$, the average viscosity found in this study for plutonic magmas, gives $\lambda=10^{-65}$, which implies that granitic magmas have little chance of ending their crustal travel as diapirs. Note that even if the speed of propagation is decreased by 5 orders of magnitude (i.e., $c=10^{-5} \mathrm{~m} \mathrm{~s}^{-1}$ ), the magma will still ascend as a dike. The parameter $\lambda$ may approach, however, values close or higher than 1 at very small ascent distances $(d=10-100 \mathrm{~m})$, and the emplacement level would be close, in fact, to the melt generation level.

The diking mechanism is characterized by rapid flow of the melt, which prevents crystallization and contamination during uprise [Clemens and Mawer, 1992], and explains the crystalpoor character of the magmas at the end of their crustal travel. Thus, for magmas that are produced by partial melting of the middle-lower continental crust and since pressure variations of less than $1 \mathrm{GPa}$ have a negligible effect on melt viscosity [Burnham, 1964; Schulze et al., 1996; Scaillet et al., 1996], the viscosity-temperature trend of Figure 2 suggests that melt extraction from the partially molten source region also occurs for viscosities around $10^{4}-10^{5} \mathrm{~Pa} \mathrm{~s}$. Viscosities of liquids produced in fluid-absent melting experiments carried out on crustal protoliths are in the range $10^{3}-10^{5} \mathrm{~Pa} \mathrm{~s}$ [Rushmer, 1995; Wolf and Wyllie, 1995], which supports this conclusion. It should be stressed that the different granites considered in this study, although originating by fluid-absent melting processes, differ in the nature of the main hydrous phase involved in the melting reaction [Whitney, 1988]. Yet they all lie on the same viscosity-temperature trend, which indicates that the nature of the melting reaction has little influence on melt segregation and separation from its source region. In the same way, the extent of melting, which may vary depending on the nature and abundance of the hydrous phase breaking down (from 10 to $50 \%$ ), appears not to be the critical factor triggering upward melt migration. The experimental data on plutonic rocks imply that granitic melts should be nearly perfectly extracted from their source with little entrainment of restites [see Clemens and Mawer, 1992].The fact that there is no crustal, restite-poor, granite magma emplaced with melt viscosities demonstrably higher than $10^{5} \mathrm{~Pa} \mathrm{~s}$, suggests that this value also represents a viscosity threshold above which no melt can migrate alone (i.e., without restites), whatever the $P$ - $T$-conditions and the state of stress in the source.

The overall viscosity pattern clearly indicates that the volcanic-plutonic dichotomy does not arise from rhyolites being systematically less viscous than granites. It demonstrates also that viscosity cannot control the level of emplacement of silicic magmas. Factors like regional or local tectonic stress fields [e.g., Scaillet et al., 1995] or the mechanical properties of the traversed terranes [e.g., Hogan and Gilbert, 1995] are more likely causes for the trapping of silicic magmas in the crust [see Clemens and Mawer, 1992]. In contrast to viscosity, density is probably one of the key factors that will control the ultimate level of emplacement of magmas. However, there is no consensus about the actual value of the partial molar volume of water dissolved in silicate melts, as well as about the possible compositional dependency of this parameter [Lange, 1994]. In addition, as emphasized in section 3, most silicic-intermediate magmas are saturated in a fluid phase [e.g., Wallace et al., 1995], which seriously complicates density calculations. For instance, assuming for simplicity a crystal+melt density of $2.4 \mathrm{~g} \mathrm{~cm}^{-3}$ and a fluid $\left(\mathrm{H}_{2} \mathrm{O}\right)$ density of $0.5 \mathrm{~g} \mathrm{~cm}^{-3}$, the magma density decreases between 2.31 and 2.02 $\mathrm{g} \mathrm{cm}^{-3}$ if its fluid content increases from 1 to $5 \mathrm{wt} \%$, i.e., a density variation similar to that arising from a temperature change exceeding $1000^{\circ} \mathrm{C}$ [see Lange and Carmichael, 1990]. This outlines the dramatic importance that the fluid phase may have on magma density. The large uncertainties that still surround this last factor make the results of density calculations for magmas highly model-dependent, and for these reasons such calculations were not attempted in this study.

\section{Concluding Statements}

One of the striking features of this study is that silicic magmas display not only an upper limit in viscosity but also a lower one. Although the former limit is understandable from a rheological point of view (i.e., the magma becomes too viscous to flow), the reasons for the latter are less obvious. However, silicic magmas with a viscosity lower than $10^{4} \mathrm{~Pa} \mathrm{~s}$ are apparently not produced. This compilation illustrates that besides their anhydrous composition, two main variables can lower the viscosity of silicic magmas, temperature and volatile contents. However, as discussed below, neither temperature 
nor the volatile content can be expected to vary so as to decrease the viscosity of silicic magmas beyond the lower viscosity threshold displayed in Figure 1. In order to decrease significantly the viscosity of silicic magmas, temperatures largely in excess of $1000^{\circ} \mathrm{C}$ would be required (Figure 2). Nevertheless, at least for modern geological periods (i.e., postArchaean), the geothermal regime of the continental crust prevents such high temperatures from being reached, even in thinned continental crust. Ponding of hot mafic magmas at the base of the crust can induce partial melting, but thermal modeling indicates that the temperature of silicic magmas generated in this way hardly exceeds $950^{\circ} \mathrm{C}$ [Huppert and Sparks, 1988]. In addition, the produced melts, although hot, will also be dry owing to the low $\mathrm{H}_{2} \mathrm{O}$ content of most highgrade metamorphic rocks [e.g., Clemens and Vielzeuf, 1987]. If free $\mathrm{H}_{2} \mathrm{O}$ is present, then melting of crustal lithologies at temperatures around $1000^{\circ} \mathrm{C}$ will not yield rhyolitic magmas but, instead, andesitic magmas or even more mafic compositions. Protracted fractional crystallization of mafic magmas, on the other hand, can produce silicic derivatives [e.g., Helz, 1987] but only at temperatures below $1000^{\circ} \mathrm{C}$, especially under $\mathrm{H}_{2} \mathrm{O}$-rich conditions [e.g., Sisson and Grove, 1993].

An increase in the water content of the melt to decrease its viscosity is the other possibility to obtain a melt viscosity significantly lower than $10^{4} \mathrm{~Pa}$ s. However, owing to the range of pressures at which most extrusive magmas are stored (200$300 \mathrm{MPa}$ ), the maximum water solubility of a rhyolitic melt will be in the range 6-7 wt \%, and the corresponding melt viscosity will be again in the range $10^{4}-10^{5} \mathrm{~Pa} \mathrm{~s}$, depending on temperature. Clearly, a silicic melt at $1000^{\circ} \mathrm{C}$ and with $7 \mathrm{wt}$ $\% \mathrm{H}_{2} \mathrm{O}$ will have a very low viscosity but, again, there are no known geological mechanisms able to produce such conditions, in keeping with the strong inverse correlation of Figure 1 that demonstrates that $\mathrm{H}_{2} \mathrm{O}$ and temperature are not independent parameters in magmas. Another parameter to be considered is the presence of volatiles other than $\mathrm{H}_{2} \mathrm{O}$ that have a lowering effect upon viscosity ( $B$ or F). However, despite the fact that these elements have an additive effect on viscosity ( $\mathrm{F}$ and $\mathrm{H}_{2} \mathrm{O}$ ) [Baker and Vaillancourt, 1995], the available evidence (Macusani and Spor Mountain) shows that there is an inverse correlation between the abundance of water and that of other fluxing elements, so that the net effect on viscosity is not expected to be large. A possible major exception to this rule is provided by strongly peralkaline rhyolites whose water solubility can be noticeably higher than 6-7 wt \% at 200-300 $\mathrm{MPa}$, as shown experimentally [e.g., Linnen et al., 1996; Dingwell et al., 1997], with corresponding low viscosities [Dingwell et al., 1998]. Such magmas may well display viscosities lower than $10^{4} \mathrm{~Pa} \mathrm{~s}$ before eruption. Thus, apart maybe from peralkaline magmas, the above lines of evidence suggest that whatever is the mechanism that produces a silicic melt, the magma most inevitably ends in a quite narrow viscosity window, which is defined both by the strong control that pressure exerts on volatile solubilities in silicate melts and by the thermal limitations required to produce acid magmas.

Considering the strain rates in silicic magma chambers, it is expected that the magma rheology falls in the Newtonian domain. In general, the available evidence suggest that the role of bubbles on magma rheology can be neglected, but examples like the El Chichón magma show that the fluid phase may be an important rheological factor. In this respect, we note that magmas with restored high fluid contents are also those with high crystal contents, which intuitively makes sense, since the amount of fluid must come in part from the crystallization of anhydrous minerals. However, the mechanisms at work in arc magmas are much more complicated than those arising from a simple closed crystallization mechanism. Processes like mixing with mafic magmas can seriously complicate this scenario. This parameter needs to be specifically addressed for each single volcanic event, and we encourage that such type of studies be carried out in the future. Important and immediate applications of such data would be to accurately estimate magma densities. For plutonic rocks there are no, as yet, methods to estimate the potential importance of fluids at the magmatic stage, though some were clearly rich in water at early stages of their evolution [Scaillet et al., 1995]. The diking mode of magma ascent implies high ascent rates and, in turn, high strain rates. Under these conditions, as with eruptive phenomena, bubbles will increase magma viscosity. However, if we take the comparison done in this work at face value, there are no reasons to believe that plutonic magmas display higher fluid contents than their volcanic counterparts. Instead, the current consensus is that crustally derived granitic magmas are generated, and most probably evolved, under fluid-absent conditions [i.e., Clemens and Vielzeuf, 1987].

Acknowledgement. This study was financiated by grants from the IDYL research program of the CNRS. Informal reviews done by José Pons and Ray Macdonald are greatly appreciated. The official reviews done by F. Spera, J. Crisp and D. Dingwell are gratefully acknowledged.

\section{References}

Anderson, A. T., S. Newman, S.N. Williams, T.H. Druitt, C. Skirius, and E. Stolper, $\mathrm{H}_{2} \mathrm{O}, \mathrm{CO}_{2}, \mathrm{Cl}$, and gas in Plinian and ash-flow Bishop rhyolite, Geology, 17, 221-225, 1989.

Bacon, C.R., S. Newman, and E. Stolper, Water, $\mathrm{CO}_{2}, \mathrm{Cl}$, and $\mathrm{F}$ in melt inclusions in phenocrysts from three Holocene explosive ruptions, Crater Lake, Oregon, Am. Mineral., 77, 1021-1030, 1992.

Bagdassarov, N.S., and D.B. Dingwell, Rheological investigations of vesicular thyolite, $J$. Volcanol. Geotherm. Res., 50, 307-322, 1992.

Bagdassarov, N.S., and D.B. Dingwell, Frequency dependent rheology of vesicular thyolite, J. Geophys. Res., 98, 6477$6487,1993$.

Bagdassarov, N.S., D.B. Dingwell, and S.L. Webb, Viscoelasticity of crystal- and bubbles-bearing rhyolite melts, Phys. Earth Planet. Inter., 83, 83-99, 1994.

Baker, D.B., Granitic melt viscosities: Empirical and configurational entropy models for their calculation, $A m$. Mineral., 81, 126-134, 1996.

Baker, D. B., and J. Vaillancourt, The low viscosities of $\mathrm{F}+\mathrm{H}_{2} \mathrm{O}$-bearing granitic melts and implications for melt extraction and transport, Earth Planet. Sci. Lett., 132, 199$211,1995$.

Barclay, J., M.J. Rutherford, M.R. Carroll, M.D. Murphy, J.D. Devine, J. Gardner, and R.S.J. Sparks, Experimental phase equilibria constraints on pre-eruptive storage conditions of the Soufriere Hills magma, Geophys. Res. Lett., in press, 1998.

Bottinga, Y., Rheology and rupture of homogeneous silicate liquids at magmatic temperatures, J. Geophys. Res., 99, 9415-9422, 1994.

Brandeis, G., and C. Jaupart, On the interaction between convection and crystallization in cooling magmas chambers, Earth Planet. Sci. Lett., 77, 345-361, 1986.

Brandeis, G., and B.D. Marsh, The convective liquidus in a solidifying magma chamber: A fluid dynamic investigation, Nature, 339, 613-616, 1989. 
Brandeis, G., C. Jaupart, and C.J. Allègre, Nucleation, crystal growth and the thermal regime of cooling magmas, $J$. Geophys. Res., 89, 10161-10177, 1984.

Burnham, C.W., Viscosity of a water rich pegmatite melt at high pressures, Spec. Pap. Geol. Soc. Am., 76, 26, 1964.

Clemens, J.D., Water contents of silicic to intermediate magmas, Lithos, 17, 273-287, 1984.

Clemens, J.D., and C.K. Mawer, Granitic magma transport by fracture propagation, Tectonophysics, 204, 339-360, 1992.

Clemens, J.D., and D. Vielzeuf, Constraints on melting and magma production in the crust, Earth Planet. Sci. Lett., 86, 287-306, 1987.

Clemens, J.D., and V.J. Wall, Crystallization and origin of some peraluminous (S-type) granitic magmas, Can. Mineral., 19, $111-131,1981$.

Clemens, J., J. Holloway, and A.J.R. White, Origin of an A-type granite: Experimental constraints, Am. Mineral., 71, 317 . $324,1986$.

Deloule, E., O. Paillat, M. Pichavant, and B. Scaillet, Ion microprobe determination of water in silicate glasses: Methods and applications, Chem. Geol., 125, 19-28, 1995.

Devine, J.D., J.E. Gardner, H.P. Brack, G.D. Layne, and M.R. Rutherford, Comparison of microanalytical methods for estimating $\mathrm{H}_{2} \mathrm{O}$ contents of silicic volcanic glasses, $\mathrm{Am}$. Mineral., 80, 319-328, 1995.

Dingwell, D.B., and S.L. Webb, Relaxation in silicate melts, Eur. J. Mineral., 2, 427-449, 1990.

Dingwell, D.B., R. Knoche, S.L. Webb, and M. Pichavant, The effect of $\mathrm{B}_{2} \mathrm{O}_{3}$ on the viscosity of haplogranitic liquids, $\mathrm{Am}$. Mineral., 77, 457-461, 1992.

Dingwell, D.B., N.S. Bagdassarov, J. Bussod, and S.L. Webb, Magma rheology, in: Short Handbook on Experiments at High Pressure and Applications to the Earth's Mantle, vol. 21, edited by R.W. Luth, pp. 131-196, Mineral. Assoc. Canada., Ontario, 1993.

Dingwell, D.B., C. Romano, and K.U. Hess, The effect of water on the viscosity of a haplogranitic melt under P-T-X conditions relevant to silicic volcanism, Contrib. Mineral. Petrol., 124, 19-28, 1996.

Dingwell, D.B., F. Holtz, and H. Behrens, The solubility of $\mathrm{H}_{2} \mathrm{O}$ in peralkaline and peraluminous granitic melts, $A m$. Mineral., 82, 434-437, 1997.

Dingwell, D.B., K.U. Hess, and C. Romano, Extremely fluid behavior of hydrous peralkaline rhyolites, Earth Planet. Sci. Lett., 158, 31-38, 1998.

Dunbar, N.W., and R.L. Hervig, Petrogenesis and volatile stratigraphy of the Bishop Tuff: Evidence from melt inclusion analysis, J. Geophys. Res., 97, 15129-15150, $1992 \mathrm{a}$.

Dunbar, N.W., and R.L. Hervig, Volatile and trace elements composition of melt inclusions from the Lower Bandelier Tuff: Implications for magma chamber processes and eruptive style, J. Geophys. Res., 97, 15151-15170, 1992b.

Dunbar, N.W., P.R. Kyle, and C.J.N. Wilson, Evidence for limited zonation in silicic magma systems, Taupo Volcanic Zone New Zealand, Geology, 17, 234-236, 1989a.

Dunbar, N.W., R.L. Hervig, and P.R. Kyle, Determination of pre-eruptive $\mathrm{H}_{2} \mathrm{O}, \mathrm{F}, \mathrm{Cl}$ contents of silicic magmas using melt inclusions: Examples from Taupo volcanic center, New Zealand, Bull. Volcanol., 51, 177-184, $1989 \mathrm{~b}$.

Emerman, S.H., and R. Marret, Why dikes?, Geology, 18, 231233, 1990.

Gardner, J.E., S. Carey, H. Sigurdsson, and M. Rutherford, Influence of magma composition on the eruptive activity of Mount St. Helens, Washington, Geology, 23, 523-526, 1995 a.

Gardner, J.E., M. Rutherford, S. Carey, and H. Sigurdsson, Experimental constraints on pre-eruptive water contents and changing magma storage prior to explosive eruptions of Mount St. Helens volcano, Bull. Volcanol., 57, 1-17, $1995 \mathrm{~b}$.

Gerlach, T.M., H.R. Westrich, and R.B. Symonds, Pre-eruption vapor in magma of the climactic Mount Pinatubo eruption: Source of the giant stratospheric sulfur dioxide cloud, in
Fire and Mud: Eruptions and Lahars of Mount Pinatubo, edited by C.G. Newhall and R. Punongbayan, pp. 415-434, Univ. of Wash. Press, Seattle, 1996.

Ghiorso, M.S., and R.O. Sack, Fe-Ti oxide geothermometry: Thermodynamic formulation and the estimation of intensive variables in silicic magmas, Contrib. Mineral. Petrol., 108, 485-510, 1991.

Helz, R. T., Differentiation behavior of Kilauea Iki lava lake, Kilauea volcano, Hawaii: An overview of past and current work, in Magmatic Processes: Physicochemical Principles, vol. 1, edited by B.O. Mysen, pp. 241-258, The Geochem. Soc., Pennsylvania, 1987.

Hervig, R.L., N. Dunbar, H.R. Westrich, and P.R. Kyle, Preeruptive water content of rhyolitic magmas as determined by ion microprobe analyses of melt inclusions in phenocrysts, J. Volcanol. Geotherm. Res., 36, 293-302, 1989.

Hess, K.U., and D.B. Dingwell, Viscosities of hydrous leucogranite melts: A non-arrhenian model, Am. Mineral., $81,1297-1300,1996$.

Hogan, J. P., and M. C. Gilbert, The A-type Mount Scott granite sheets: Importance of crustals magmas traps, $J$. Geophys. Res., 100, 15779-15792, 1995.

Huppert, H.E., and R.S.J. Sparks, The generation of granitic magmas by intrusion of basalt into continental crust, $J$. Petrol., 29, 599-624, 1988.

Johnson, M.C., and M.C. Rutherford, Experimentally determined conditions in the Fish Canyon Tuff, Colorado, magma chamber, J. Petrol., 30, 711-737, 1989.

Johnson, M.C., A.T. Anderson, and M.J., Rutherford, Preeruptive volatile contents of magmas, in Volatiles in Magmas, Rev. Mineral., vol. 30, edited by M.R. Carroll and J.R Holloway, pp. 281-330, Mineral. Soc. of Am., Washington, D.C., 1994.

Keith, J.D., and W.C. Shanks III, Chemical evolution and volatile fugacities of the Pine grove porphyry molybdenum and ash-flow tuff system, southwestern Utah, in Recent Advances in the Geology of Granite-Related Mineral Deposits, edited by R.P. Taylor and D.F. strong, Spec. Vol. Can. Inst. Min. Metall., 39, 402-423, 1988.

Lange, R.A., The effect of $\mathrm{H}_{2} \mathrm{O}, \mathrm{CO}_{2}$ and $\mathrm{F}$ on the density and viscosity of silicate melts, in Volatiles in Magmas, Rev. Mineral., vol. 30, edited by M.R. Carroll and J.R. Holloway, pp. 331-369, Mineral. Soc. of Am., Washington, D.C., 1994.

Lange, R.A., and I.S.E. Carmichael, Thermodynamic properties of silicate liquids with emphasis on density, thermal expansion and compressibility, in Modern Methods in Igneous Petrology: Understanding Magmatic Processes, Rev. Mineral., vol. 24, edited by J. Nicholls and J.K. Russell, pp. 25-64, Mineral. Soc. of Am., Washington, D.C., 1990.

Lejeune, A., and P. Richet, Rheology of crystal-bearing silicate melts: An experimental study at high viscosities, $J$. Geophys. Res., 100, 4215-4229, 1995.

Linnen, R.B., M. Pichavant, and F. Holtz, The combined effects of $\mathrm{fO}_{2}$ and melt composition on $\mathrm{SnO}_{2}$ solubility and tin diffusivity in haplogranitic melts, Geochim. Cosmochim. Acta, 60, 4965-4976, 1996.

Lowenstern, J.B., Evidence for a copper-bearing fluid in magma erupted at the Valley of Ten Thousand Smokes, Alaska, Contrib. Mineral. Petrol., 114, 409-421, 1993.

Lowenstern, J.B., Dissolved volatile concentrations in an oreforming magma, Geology, 22, 893-896, 1994.

Luhr, J., Experimental phase relations of water- and sulfursaturated arc magmas and the 1982 eruptions of El Chichón volcano, J. Petrol., 31, 1071-1114, 1990.

Maaloe, S., and P.J. Wyllie, Water content of a granite magma deduced from the sequence of crystallization determined experimentally with water-undersaturated conditions, Contrib. Mineral. Petrol., 52, 175-191, 1975.

Mandeville, C.W., S. Carey, and H. Sigurdsson, Magma mixing, fractional crystallization and volatile degassing during the 1883 eruption of Krakatau volcano, Indonesia, J. Volcanol. Geotherm. Res., 74, 243-274, 1996. 
Marsh, B., On the crystallinity, probability of occurence and rheology of lava and magma, Contrib. Mineral. Petrol., 78, 85-98, 1981 .

Marsh, B., On the convective style and vigour in sheet-like magma chambers, J. Petrol., 30, 479-530, 1989.

Martel, C., M. Pichavant, J.L. Bourdier, H. Traineau, F. Holtz, and $\mathrm{B}$. Scaillet, Magma storage and control of eruption regime in silicic volcanoes: Experimental evidence from Mt. Pelée, Earth Planet. Sci. Lett., 156, 89-99, 1998.

McBirney, A. R., and T. R. Murase, Rheological properties of magmas, A. Rev. Earth Planet. Sci., 12, 1-10, 1984.

Newman, S., E.M. Stolper, and S. Epstein, Measurement of water in rhyolitic glasses: Calibration of an infrared spectroscopic technique, Am. Mineral., 7l, 1527-1541, 1986.

Petford, N., R.C. Kerr, and J.R Lister, Dike transport of granitoid magmas, Geology, 21, 845-848, 1993.

Pichavant, M., D.J. Kontak, J.Valencia Herrera, and A.H. Clark, The Miocene-Pliocene Macusani Volcanics, SE Peru, I; Mineralogy and magmatic evolution of a two-micas aluminosilicate-bearing ignimbrite suite, Contrib. Mineral. Petrol., 100, 300-324, 1988a.

Pichavant, M., D.J. Kontak, L. Briqueu, J.Valencia Herrera, and A.H. Clark, The miocene-Pliocene Macusani Volcanics, SE Peru, II; Geochemistry and origin of a felsic peraluminous magma, Contrib. Mineral. Petrol., 100, 325-338, 1988 b.

Pinkerton, H., and R.J. Stevenson, Methods of determining the rheological properties of magmas at sub-liquidus temperatures, J. Volcanol. Geotherm. Res., 53, 47-66, 1992.

Rushmer, T., An experimental deformation study of partially molten amphibolite: Application to low-melt fraction segregation, J. Geophys. Res., I00, 15681-15695, 1995.

Rutherford, M.J., and J. Devine, Pre-eruption pressuretemperature conditions and volatiles in the 1991 dacitic magma of Mount Pinatubo, in Fire and Mud: Eruptions and Lahars of Mount Pinatubo, edited by $C$. Newhall and R. Punongbayan, pp.751-766 , Univ. of Wash. Press, Seattle, 1996.

Rutherford, M.J., H. Sigurdsson, S. Carey, and A. Davis, The May 18, 1980, eruption of Mount St. Helens, 1, Melt composition and experimental phase equilibria, J. Geophys. Res., 90, 2929-2947, 1985.

Rutherford, M.H., J.D. Devine, and J. Barclay, Changing magma conditions and ascent rates during the Soufriere Hills eruptions on Montserrat, GSA Today, 8, 1-7, 1998.

Scaillet, B., and B.W. Evans, The June 15, 1991 eruption of Mount Pinatubo, I, Phase equilibria and pre-eruption P-T$\mathrm{fO}_{2}-\mathrm{fH}_{2} \mathrm{O}$ conditions of the dacite magma, $J$. Petrol., in press, 1998 .

Scaillet, B., M. Pichavant, and J. Roux, Experimental crystallization of leucogranite magmas, J. Petrol., 36, 664706, 1995.

Scaillet, B., F. Holtz, M. Pichavant, and M. Schmidt, Viscosity of Himalayan leucogranites: Implications for mechanisms of granitic magma ascent, J. Geophys. Res., I0I, 27691-27699, 1996.

Scaillet, B., B. Clemente, B.W. Evans, and M. Pichavant, Redox control of sulfur degassing in silicic magmas, J. Geophys. Res., in press, 1998.

Schulze, F., H. Behrens, F. Holtz, J. Roux, and W. Johannes, The influence of water on the viscosity of a haplogranite liquid, Am. Mineral. 81, 1155-1165, 1996.

Shaw, H.R., Viscosities of magmatic silicate liquid: An empirical method of prediction, Am. $J$ Sci., 272, 870-893, 1972.

Sisson, T.W., and T.L. Grove, Experimental investigations of the role of $\mathrm{H}_{2} \mathrm{O}$ in calc-alkaline differentiation and subduction zone magmatism, Contrib. Mineral. Petrol., 113, 143-166, 1993.

Skirius, C.M., J.W. Peterson, and A.T. Anderson, Homogenizing rhyolitic glass inclusions from the Bishop Tuff, Am. Mineral., 75, 1381-1398, 1990.
Spera, F.J., A. Borgia, J. Strimple, and M. Feigenson, Rheology of melts and magmatic suspensions, 1, Design and calibration of concentric cylinder viscometer with application to rhyolitic magma, J. Geophys. Res., 93, 10273-10294, 1988.

Stein, D.J., and F.J. Spera, Rheology and microstructure of magmatic emulsions: Theory and experiments, J. Volcanol. Geotherm. Res., 49, 157-174, 1992.

Stein, D.J., and F.J. Spera, Rheometry of a dacitic melt: Experimental results and tests of empirical models for viscosity estimation, Geophys. Res. Lett., 20, 1923-1926, 1993.

Stix, J., and M.P. Gorton, Variations in sanidine partition coefficients in the Cerro Toledo Rhyolite, Jemez Mountains, New Mexico: Effects of composition, temperature, and volatiles, Geochim. Cosmochim. Acta, 54, 2697-2708, 1990a.

Stix, J., and M.P. Gorton, Changes in silicic melt structure between the two Bandelier caldera-forming eruptions, New Mexico, USA: Evidence from zirconium and light rare earth elements, J. Petrol., 31, 1261-1283, 1990b.

Stix, J., and G.D. Layne, Gas saturation and evolution of volatile and light lithophile elements in the Bandelier magma chamber between two caldera-forming eruptions, $J$. Geophys. Res., 101, 25181-25196, 1996.

Wall, V.J., J.C. Clemens, and D.B. Clarke, Models of granitoid evolution and source compositions, J. Geol., 95, 731-749, 1987.

Wallace, P.J., and T.M. Gerlach, Magmatic vapor source for sulfur dioxide released during volcanic eruptions: Evidence from Mount Pinatubo, Science, 265, 497-499, 1994.

Wallace, P.J., A.T. Anderson, and A.M. Davis, Quantification of pre-eruptive exsolved gas contents in silicic magmas, Nature, 377, 612-616, 1995.

Warshaw, C., and R.L. Smith, Pyroxenes and fayalites in the Bandelier Tuff, New Mexico: Temperatures and comparison with other rhyolites, Am. Mineral., 73, 1025-1037, 1988.

Webb, S.L., and D.B. Dingwell, Non-newtonian rheology of igneous melts at high stresses and strain rates: Experimental results for rhyolite, andesite, basalt and nephelinite, J. Geophys. Res., 95, 15695-15701, 1990.

Webster, J.D., J.R. Holloway, and R.L. Hervig, Phase equilibria of a $\mathrm{Be}, \mathrm{U}$ and $\mathrm{F}$-enriched vitrophyre from Spor Mountain, Utah, Geochim. Cosmochim. Acta, 51, 389-402, 1987.

Webster, J.D., R.P. Taylor, and C. Bean, Pre-eruptive melt composition and constraints on degassing of a water-rich pantelleritic magma, Fantale volcano, Ethiopia, Contrib. Mineral. Petrol., 114, 53-62, 1993.

Westrich, H.R., and T. M. Gerlach, Magmatic gas source for the stratospheric $\mathrm{SO}_{2}$ cloud from the June 15,1991 , eruption of Mount Pinatubo, Geology, 20, 867-870, 1992.

Westrich, H.R., J.C. Eichelberger, and R.L. Hervig, Degassing of the 1912, Katmai magmas, Geophys. Res. Lett., 18, 15611564, 1991.

Whitney, J.A., The origin of granite: The role and source of water in the evolution of granitic magmas, Geol. Soc. Am. Bull., 100, 1886-1897, 1988.

Wolf, M. B. and P.J. Wyllie, Liquid segregation parameters from amphibolite dehydration melting experiments, $J$. Geophys. Res., 100, 15611-15621, 1995.

F. Holtz, Institut fur Mineralogie, Welfengarten 1, Universitat Hannover, W3000 Hannover, Germany.

M. Pichavant and B. Scaillet, CRSCM, CNRS, 1A rue de la Férollerie, 45071 Orléans cedex 02, France (bscaille@cnrs-orleans.fr)

(Received January 26, 1998; revised June 8, 1998; accepted July 20, 1998.) 